\title{
DOI-CODI II EXÉRCITO: A EXPERIÊNCIA DE PRESERVAÇÃO DE UM PATRIMÔNIO SENSÍVEL
}

\section{DEBORAH REGINA LEAL NEVES (UNICAMP/UPPH)}

Universidade Estadual de Campinas - Unidade de Preservação do Patrimônio Histórico deca.neves@gmail.com

\section{Resumo:}

O DOI-CODI, em São Paulo (Brasil) foi um órgão de repressão que funcionou entre 1969 e 1983 e tinha como principal objetivo a perseguição a opositores da Ditadura Civil-Militar (19641985). Em 2010, um grupo de entidades de defesa dos Direitos Humanos solicitou a preservação dos prédios como patrimônio cultural do estado de São Paulo. O artigo tem como objetivo discutir o processo que levou à preservação do conjunto de edifícios, abordando os métodos de pesquisa, as discussões teóricas e os conflitos presentes neste caso emblemático.

\section{Palavras-chave:}

Patrimônio cultural - DOI-CODI - Condephaat - Ditadura Civil-Militar

\author{
Abstract: \\ discussions and the conflicts present in this emblematic case.

\section{Keywords:} \\ Cultural heritage - DOI-CODI - Condephaat - Civil-Military Dictatorship
}

The DOI-CODI, in São Paulo (Brazil) was a repressive organ that operated between 1969 and 1983 and had as main objective the persecution of opponents of the Civil-Military Dictatorship (1964-1985). In 2010, a group of human rights defense entities requested the preservation of buildings as cultural heritage of the state of São Paulo. The article aims to discuss the process that led to the preservation of the set of buildings, addressing the research methods, the theoretical 


\title{
DOI-CODI II EXÉRCITO: A EXPERIÊNCIA DE PRESERVAÇÃO DE UM PATRIMÔNIO SENSÍVEL
}

\author{
DEBORAH REGINA LEAL NEVES (UNICAMP/UPPH) \\ Universidade Estadual de Campinas - Unidade de Preservação do Patrimônio Histórico \\ deca.neves@gmail.com
}

\section{Introdução}

O presente artigo tem base no trabalho empreendido como técnica do Condephaat, ao instruir o Parecer Técnico UPPH $n^{\circ}$ GEI-256-2012, em resposta ao pedido de tombamento ${ }^{1}$ do conjunto de edifícios que abrigou o DOI-CODI, maior centro de tortura e repressão do país, localizado na cidade de São Paulo. A prática de preservação do patrimônio material edificado no Brasil foi institucionalizada em 1937, e no estado de São Paulo, desde 1968 por meio do Condephaat Conselho de Defesa do Patrimônio Histórico, Artístico, Arqueológico e Turístico do Estado de São Paulo.

Nascido no período de maior tensão da Ditadura Civil-Militar, a criação do órgão estadual de preservação é consonante com a política federal de valorização do turismo por meio da ampliação da base de patrimônio cultural reconhecida oficialmente pelo Estado. Ao contrário da prática de até então, o patrimônio não estava mais intrinsecamente ligado à noção de construção de identidade comum por meio da arquitetura, mas sim o culto ao passado como um objeto de consumo da indústria cultural, em franca ascensão naquele momento ${ }^{2}$.

Ao longo da história do Condephaat, foram reconhecidos como patrimônio cultural exemplares arquitetônicos considerados importantes visando a construção de um acervo que colocasse o Estado de São Paulo no roteiro turístico do Brasil, que investia fortemente nessa propaganda no exterior. Essa seleção de exemplares privilegiou aquilo que se classifica como "História Oficial": as fazendas - em especial cafeeiras -, igrejas católicas e conjuntos urbanos coloniais - incluindo exemplares de sítios arqueológicos.

A partir da década de 1980, a sociedade passou a demandar do Condephaat o reconhecimento de locais que remetiam a outras memórias para além daquelas já consagradas. O contexto era o da distensão da Ditadura e o caminho para a redemocratização do país, e os pedidos refletem esse momento. Destacam-se, neste período, os seguintes pedidos de tombamento:

a. Teatro Oficina em 1982, cuja sede ocupada desde o fim da década de 1960 pelo Grupo Uzina Uzona, reconhecido como resistente à Ditadura, estava ameaçada de demolição após a compra de vários imóveis vizinhos para a construção de um grande empreendimento comercial;

\footnotetext{
${ }^{1}$ No Brasil, para o reconhecimento de lugares como patrimônio cultural, utiliza-se a palavra "tombamento". O termo é oriundo de Portugal, onde no século XIV foi criado um arquivo em uma das torres da muralha de Lisboa, depois denominada Torre do Tombo. A origem do termo tombo é o português arcaico e remete à prática de inscrever em Livros tudo aquilo que é relevante, como um inventário.

2 RODRIGUES, Marly. Imagens do passado. A instituição do patrimônio em São Paulo (1969-1987). São Paulo: Ed. UNESP; Imprensa Oficial; Condephaat; FAPESP, 2000, p.46.
} 
b. Arco do Presídio Tiradentes, construído em 1850 com a expansão da cidade de São Paulo, utilizado no século XX como presídio político tanto na Ditadura Vargas (19371945) como na Civil-Militar, até sua demolição para a construção de uma estação do metrô (1972). Desta demolição, restou apenas um arco, que ficava na muralha externa do presídio, cuja preservação foi solicitada como marco de memória da resistência à ditadura;

c. Edifício da Faculdade de Filosofia, Ciências e Letras da Universidade de São Paulo (USP), conhecida como "Prédio da Maria Antônia", que em 1968 foi alvo de ataques de grupos anticomunistas formados predominantemente por alunos da Universidade Presbiteriana Mackenzie. O edifício da USP abrigava cursos de ciências humanas e exatas, cujos alunos em sua maioria eram opositores do regime à época. $\mathrm{Na}$ noite do dia 02/10/1968, alunos das duas instituições se enfrentaram num episódio que ficou conhecido como "Batalha da Maria Antônia";

d. Terreiro de Candomblé Axé Ilê Obá, um dos maiores e mais importantes da cidade de São Paulo, foi bastante inovador por ser o primeiro tombamento "não-católico", mas também por ser um espaço de formação de sacerdotes de Candomblé3.

Além de terem em comum o período da redemocratização, o que conformava também a ampliação do que é patrimônio cultural - cuja Constituição de 1988 foi determinante para ampliar o conceito e sua natureza - esses locais todos guardam a semelhança de não terem importância arquitetônica e sim histórico-cultural para o estado de São Paulo. Tratava-se de uma mudança de mentalidade tanto da sociedade, que por si só começava a compreender que o patrimônio era mais amplo que aquele já reconhecido pelos órgãos oficiais, como do próprio órgão que, recebendo tais pedidos, deu encaminhamento no sentido de acolher a argumentação social, a despeito da estética, até então requisito importante para a preservação.

Em termos de reconhecimento de lugares "não convencionais" como patrimônio cultural, há uma lacuna importante na década de 1990. Os técnicos da preservação do Condephaat arquitetos, historiadores e geógrafos - foram paulatinamente de desligando do serviço, especialmente por precariedade de condições de trabalho (como baixos salários, falta de estrutura para realizar vistorias e elaboração de estudos), praticamente inviabilizando novos tombamentos durante o período. A política neoliberal, importante e impactante não só no Brasil, mas na América Latina, foi determinante, marcando as políticas de preservação por "desregulamentação" - a submissão da vida social ao capital privado - e "flexibilização" - adaptação permissiva da legislação, incluindo a paralisação de estudos de tombamento, para beneficiar o capital ${ }^{4}$.

O tombamento mais expressivo deste período ocorreu em 1999, quando o Condephaat reconheceu o prédio que abrigou o Departamento de Ordem Política e Social (DOPS) como patrimônio cultural. O estudo foi iniciado em 1976, tendo o prédio como parte de um conjunto mais amplo de imóveis, listados como relevantes para preservação, face ao avanço do mercado imobiliário na região central da cidade. Com receio de que se perdessem exemplares importantes da arquitetura, uma comissão de planejamento da cidade de São Paulo (Cogep) solicitou que o Condephaat preservasse tais imóveis. Entre eles, o DOPS, que ainda estava sendo utilizado pela polícia política.

O edifício foi construído para abrigar armazéns e escritórios de uma companhia de transporte ferroviário em 1914 pelo Escritório Técnico de Ramos de Azevedo, talvez o principal nome da arquitetura pública e privada do início do século em São Paulo. Em 1938, com a finalização de

\footnotetext{
3 Para mais informações ver AMARAL, Rita. "O tombamento de um terreiro de Candomblé em São Paulo", Comunicações do ISER no 41, ISER, Rio de Janeiro, 1991. Disponível em http://axeileoba.com.br/arquivo/publicacoes/UrbanitasRitaAmaral_Site.pdf, acessado em 08 set. 2018.

${ }^{4}$ SCIFONI, Simone. A construção do patrimônio natural. Tese (Doutorado em Geografia). Faculdade de Filosofia, Letras e Ciências Humanas, Universidade de São Paulo. São Paulo, 2006.
} 
uma nova sede para abrigar estação, armazém e escritórios, o edifício passou a ser paulatinamente ocupado pela Polícia Civil, que deixou de utilizá-lo apenas em 1997, quando foi transferido para a Secretaria da Cultura do Estado, com a finalidade de ali instalar um equipamento cultural que ressignificasse um dos principais locais de detenção, tortura e assassinato do Estado, e que serviu de modelo para outros estados, que criaram suas próprias polícias políticas.

Um aporte financeiro do Banco Interamericano de Desenvolvimento (BID) ${ }^{5}$ possibilitaria a reforma pretendida no edifício, mas para isso, ele precisaria estar tombado oficialmente. Então, sob essa circunstância, o Condephaat decidiu pelo tombamento. A arquitetura era importantíssima para o local, e por isso bastante valorizada. Porém, a importância histórica também foi reconhecida - com menos destaque - e com isso determinou-se a preservação da área que serviu de carceragem, localizada no térreo do edifício. No entanto, a reforma finalizada em 2002 não se pautou por princípios de restauro, e destruiu irreversivelmente inscrições e vestígios de detidos, além de descaracterizar completamente a ocupação policial que predominou no edifício ${ }^{6}$. Não se teve ali cuidado em compreender o espaço para além de um objeto arquitetônico, tampouco de uma memória difícil que deve ser preservada, incorrendo em uma rasura em um documento e, por conseguinte, perda para a História.

Percebe-se um aumento da confiança da sociedade civil no Estado ao acionar uma instituição para a preservação de um bem cuja carga simbólica evoca valores até então não reconhecidos na forma de tombamento, bem como a disposição técnica em refletir criticamente sobre a natureza e pertinência do pedido e ainda, a receptividade do Condephaat ao entender que essas são memórias passíveis de valorização por meio de instrumentos legais. O momento político e social foi determinante para que isso ocorresse, e no caso do DOI-CODI, não foi diferente.

\section{O que foi o Doi-Codi e sua importância}

$\mathrm{Na}$ introdução foi possível compreender o antecedente de preservação de lugares relacionados a memórias não convencionais como patrimônio cultural, demonstrando que o conhecimento e a experiência podem produzir instrumentos capazes de garantir que os principais valores de um local sejam evocados. Também é necessário, entretanto, compreender o que foi o Departamento de Operações e Informações-Centro de Operações e Defesa Interna (DOI-CODI) e a sua importância dentro do cenário de repressão política e social.

A primeira e mais importante constatação para a valoração do edifício que abrigou o DOICODI, no bairro de Vila Mariana, em São Paulo, é seu caráter embrionário para o que depois se tornou uma política de segurança pública e combate à esquerda em todo o Brasil. Criada como uma estrutura militar não institucional, destinada a suprir a necessidade de lidar com a "guerrilha urbana", a Operação Bandeirante reuniu efetivos da Secretaria de Segurança Pública, DEOPS, Centro de Informações do Exército (CIE) e do Centro de Informações Secretas da Aeronáutica (CISA), que recebiam informações e coordenavam investigações sobre a atividade da esquerda armada. Essa composição foi responsável pela prisão de integrantes da Vanguarda Popular Revolucionária (VPR), da Ação Libertadora Nacional (ALN) e da Ação Popular (AP) que resultaram no esclarecimento de diversas ações bem-sucedidas destas organizações.

\footnotetext{
5 MARINS, Paulo César Garcez. "Do Luz Cultural ao Monumenta: sobre a opção pela escala monumental na preservação de uma área de São Paulo”, em GAGLIARDI, Clarissa Rosa, et al. (coord.). Intervenções urbanas em Centros Históricos: casos da Itália e São Paulo em discussão. São Paulo: Educ/PUC, 2011.

${ }^{6}$ NEVES, Deborah Regina Leal. A persistência do passado: memoriais e patrimônio da ditadura em São Paulo e Buenos Aires. Dissertação (Mestrado em História Social). Faculdade de Filosofia, Letras e Ciências Humanas, Universidade de São Paulo. São Paulo, 2014. Disponível em www.teses.usp.br/teses/disponiveis/8/8138/tde-27062014-120128/ptbr.php
} 
Em junho de 1969, foi lançada pela Presidência da República a "Diretriz para a Política de Segurança Interna" determinando que a "responsabilidade pelo planejamento e execução das medidas para conter a subversão e o terrorismo (...)" competia aos "(...) comandantes Militares de Área do Exército", 7 atendendo ao anseio de centralizar no Exército a repressão, dispersa entre os DOPS estaduais, dando condições legais para a criação da Operação Bandeirante (OBan). Em 1 de julho de 1969, foi fundado o novo "órgão" - ainda sob o nome de OBan -, com a presença de autoridades civis e militares do estado de São Paulo e empresários; tratava-se de uma organização extralegal, já que não houve decretos, leis, atos institucionais ou complementares, não constando de qualquer organograma de Secretarias ou Ministérios e, por isso, instalou-se nas dependências da $36^{a}$ Delegacia de Polícia, na Rua Tutóia, em São Paulo, de maneira precária.

De acordo com Huggins, a OBAN foi criada secretamente com o intuito de:

"coordenar as atividades das diversas organizações policiais e militares de segurança interna do estado e facilitar a coleta rápida de informações. Sua meta mais específica era identificar, localizar e capturar grupos subversivos que operavam na Segunda Região Militar, especialmente em São Paulo, com o objetivo de destruí-los ou pelo menos, neutralizá-los'(...)". ${ }^{8}$

Mariana Joffily afirma que essa centralização se fazia necessária para conjugar a coleta de informações com a ação direta da OBan; por isso, era necessário que o interrogatório preliminar fosse bem conduzido de forma a fornecer o maior número de informações possíveis e permitir sua organização de modo a tornar inteligível a organização da esquerda. Portanto,

“Todos os órgãos desta Secretaria [de Segurança Pública] ao efetuarem prisões de indivíduos suspeitos de subversão, terrorismo, deverão providenciar o encaminhamento dos mesmos, de imediato, para a Operação Bandeirante (Rua Tutoia, 921 - Paraíso). Após o interrogatório preliminar serão encaminhados, os civis para o DEOPS e os militares para suas respectivas Corporações". ${ }^{9}$

De acordo com Kushnir ${ }^{10}$ a OBan, sob o comando de um oficial do Exército, lotado em um Centro de Inteligência do Exército (CIE), poderia requisitar efetivos à Polícia Militar, delegados e escreventes à Polícia Civil, manteria uma estrutura para tomar depoimentos, possuiria uma carceragem. O objetivo da centralização das atividades repressivas nas grandes cidades era também reduzir as rivalidades entre policiais civis e militares, colocando-os sob o mesmo comando, criando-se a polícia política dentro do Exército.

"Segundo um ex-delegado do Departamento de Investigações Criminais da Polícia Civil de São Paulo, o núcleo policial da OBan provinha de um grupo especialmente selecionado de policiais 'duros' que esse delegado havia reunido quando estava na diretoria do DEIC. Esses policiais já eram 'muito brutais' quando passaram a executar seu trabalho especializado para ele. Experientes em busca, captura e interrogatórios, esse grupo de policiais violentos foi então convidado a integrar a OBan, tornando-se o núcleo dessa organização de segurança interna notoriamente violenta." ${ }^{11}$

\footnotetext{
7 PEREIRA, Freddie Perdigão. O Destacamento de Operações de Informações (DOI) no EB - Histórico papel no combate à subversão: situação atual e perspectivas. Escola de Comando e Estado-Maior do Exército, 1978, p.6.

${ }^{8}$ HUGGINS, Martha K. Polícia e politica: relações Estados Unidos/América Latina. Trad. Lólio Lourenço de Oliveira. São Paulo: Ed. Cortez, 1998, p.175.

9 “Informação sobre a Operação Bandeirante". 02/06/1970. Arquivo do Estado de São Paulo, Fundo DOPS, Série Dossiês, 50-Z-9, 73, 13139. APUD JOFFILY, Mariana. No centro da engrenagem: os interrogatórios na Operação Bandeirante e no DOI de São Paulo. Tese (Doutorado em História Social). Faculdade de Filosofia, Letras e Ciências Humanas, Universidade de São Paulo, 2008, p.38.

${ }^{10}$ KUSHNIR, Beatriz. Cães de Guarda. São Paulo: Boitempo, 2004, p.175.

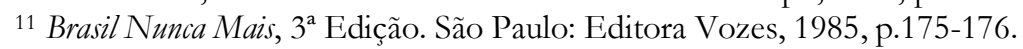


Para conquistar a confiança e a simpatia da população e legitimar as ações do Estado, as forças de segurança passaram a fazer campanhas de "conscientização" em que procuravam motivar pessoas comuns na defesa contra o terrorismo, criando correntes telefônicas e postais, tornando cada indivíduo um "policial secreto", envolvido na luta contra a subversão. Nessa rede de informantes estavam inclú́dos os empresários, responsáveis por financiar essa estrutura extra-oficial; e justamente por estar nesta condição - a ilegalidade - não havia como consignar recursos orçamentários para esta divisão: neste momento surgem indícios de financiamentos privados à estrutura, pagos pela Ford, General Motors e Ultragás (na figura do Diretor Henning Boilessen, mais tarde assassinado por militantes da ALN e do Movimento Tiradentes), Curso pré-vestibular Objetivo, Banco Mercantil, Banco Bradesco, entre outras. ${ }^{12}$ De acordo com Joffily, Antônio Delfim Neto - Ministro da Fazenda entre 1967 e 1974 - e Gastão Vidigal, dono do Banco Mercantil, reuniam donos de bancos, a FIESP e outros para pedir fundos destinados ao financiamento da atividade da OBan, a fim de garantir "a paz nos negócios". ${ }^{13}$ Inaugurava-se o financiamento privado que permitiu, inclusive, a perpetuação do modelo no DOI-CODI.

A OBan paulista, considerada um sucesso dentro de seus objetivos, foi a base para a criação do DOI-CODI, que difundiu para o Brasil o modelo criado em São Paulo. Em março de 1970, um novo documento intitulado também Diretriz Presidencial de Segurança Interna apresentou modificações no documento anterior, de 1969. A principal delas foi a constituição de um Sistema de Segurança Interna, que centralizava as ações que "garantiriam a segurança do país", priorizando a atuação do Exército e dividindo o país em quatro Zonas de Defesa Interna (ZDI), ligadas aos Comandos do Exército. A partir dessa estruturação, criou-se em cada uma das ZDI organismo colegiado chamado de Centro de Operações de Defesa Interna - CODI, que tinha como finalidade a busca de informação e a articulação institucional estratégica. Ainda em 1970, foram criados os Departamentos de Operação e Informação - DOI, subordinados à Central de Informações do CODI. A criação do DOI foi necessária, ao que indica, ${ }^{14}$ porque as informações prestadas pelo CODI precisavam ser executadas rapidamente, com redução de custo e por pessoal especializado através de treinamento específico, numa clara demonstração de descontentamento com as demais forças de segurança, até então desarticuladas. (grifos nossos)

O experimento da OBan se tornou institucional, dotando os DOI-CODI de orçamento, pessoal e sob o comando de um oficial do Exército, tornando-se o principal órgão de repressão do regime a partir de 1970. Uma vez que alguém era capturado, ficava detido em uma das celas da $36^{a}$ Delegacia de Polícia, a face "oficial" do edifício, ou numa das salas presentes num edifício dos fundos, principal local utilizado pelo Doi-Codi como local de interrogatório. Ali, as torturas eram utilizadas como método de obtenção de informações, confissões. Joffily afirma que os métodos empregados pelo DOI-CODI em seus interrogatórios viam o preso não como um ser humano, "mas como um elemento do qual era necessário extrair o máximo de dados em um mínimo de tempo" $"$. Além da tortura física, o órgão ficou também caracterizado pela tortura psicológica, em que familiares de presos - incluindo crianças - eram sequestrados ou levados até à carceragem como forma de chantagem.

\footnotetext{
12 Brasil Nunca Mais. $3^{\text {a }}$ Edição. São Paulo: Ed. Vozes, 1985, p.177 e BRASIL. COMISSÃO NACIONAL DA VERDADE. Relatório. Volume I. Capítulo 4. Órgãos e procedimentos de repressão política. Brasília, CNV, 2014, pp.127, 148 e 170.

${ }_{13}^{3}$ JOFFILY, Mariana. No centro da engrenagem. Os interrogatórios na Operação Bandeirante e no DOI de São Paulo (1969-1975). Tese (Doutorado em História Social). Faculdade de Filosofia, Letras e Ciências Humanas, Universidade de São Paulo, 2008, p.32-33.

14 PEREIRA, Freddie Perdigão. O Destacamento de Operações de Informacões (DOI) no EB - Histórico papel no combate à subversão: situação atual e perspectivas. Escola de Comando e Estado-Maior do Exército, 1978, p.5.

Disponível em http://www.prr3.mpf.gov.br/arquivos/Ditadura-Militar---A $\% \mathrm{C} 3 \% \mathrm{~A} 7 \% \mathrm{C} 3 \% \mathrm{~B} 5 \mathrm{es}-\mathrm{e}-$ Representa \%C3\%A7\%C3\%B5es/Provid \%C3\%AAncias-C \%C3\%ADveis/A\%C3\%A7\%C3\%A3o-CivilP\%C3\%BAblica---CASO-MANOEL-FIEL-FILHO/Doc06----Monografia/, acessado em 11 abr. 2013. 15 JOFFILY, Op. cit, p. 242.
} 
Em 10/05/2013, na audiência pública onde o ex-comandante do DOI-CODI de São Paulo Carlos Alberto Brilhante Ustra foi ouvido, Cláudio Fonteles - membro da Comissão Nacional da Verdade - apresentou um relatório datado de 1973, onde consta a quantidade de detidos, interrogados e mortos pelo DOI-CODI. Esse novo relatório se junta a outros dois, de 1975 localizado por Pedro Pomar no Arquivo Público do Estado de São Paulo no ano de 2000 - e de 1977 - afixado à monografia do Major Freddie Perdigão Pereira. Os três relatórios apontam para a existência de mortos no DOI-CODI (ou pelo órgão), contrariando aqui as versões de que nunca houve assassinatos no órgão. Embora Ustra insista em afirmar que os mortos aos quais se referem os relatórios foram decorrentes de "confrontos", não são as circunstâncias apuradas pela Comissão de Mortos e Desaparecidos Políticos, após a reavaliação de laudos cadavéricos, fotografias, coleta de depoimentos e até exumações. Relatórios produzidos pelo próprio órgão informam que 50 pessoas foram mortas pelo DOI-CODI e 6897 pessoas foram detidas e interrogadas naquelas dependências. A Comissão de Mortos e Desaparecidos Políticos estima que 361 pessoas foram mortas ou estão desaparecidas em decorrência da repressão do Estado em áreas urbanas, de modo então que o número de números de mortos e desaparecidos no/pelo DOI-CODI de São Paulo representa 17\% do total no Brasil. Não há dúvidas da letalidade e da relevância da prática da repressão neste local.

\section{O pedido e o estudo de tombamento do DOI-CODI}

Em 23/04/2010, ingressou na UPPH pedido de tombamento do DOI-CODI, solicitado por Ivan Akselrud Seixas, preso aos 16 anos junto com seu pai Joaquim Seixas (morto em decorrência das torturas sofridas no DOI-CODI), ambos pertencentes ao Movimento Revolucionário Tiradentes. Em seu pedido, Seixas afirma que diante "de sua importância histórica e relevante papel didático que o referido prédio tem para as gerações de jovens brasileiros, que ignoram as atrocidades ali cometidas, o tombamento garantirá a preservação desse importante documento físico de nossa História recente". Acompanham o pedido: Conselho Estadual de Defesa dos Direitos da Pessoa Humana, Grupo Tortura Nunca Mais-SP, Fórum dos ex-presos e perseguidos políticos do estado de São Paulo, Comissão de Familiares de presos mortos e desaparecidos políticos e Núcleo de Preservação de Memória Política. Trata-se, portanto, do primeiro pedido do gênero desde o tombamento do Edifício Maria Antônia, em 1988.

Em setembro de 2010, foram elaborados os pareceres técnicos que, preliminarmente, apontaram para a importância histórica do local, a despeito de sua qualidade arquitetônica. $\mathrm{O}$ intuito era reconhecer aquele como um lugar de memória, e que por isso deveria ser reconhecido. Em outubro de 2010, o processo foi encaminhado ao Conselheiro Jon Andoni Maitrejean, que o devolveu apenas em maio de 2011 sem relatoria. Encaminhado em novembro de 2011 à Conselheira Cristina Meneguello, professora de História da Unicamp, a mesma o devolveu com relato favorável à abertura de Estudo de Tombamento - fase em que o imóvel fica previamente protegido -, cuja indicação foi acatada por unanimidade pelo Condephaat em 14/05/2012. A partir daí, um amplo estudo passou a ser realizado, visando construir uma proposta de tombamento que abrangesse toda a potencialidade que os imóveis apresentavam.

Para realizar tarefa de tamanha importância para a História do país e do próprio Patrimônio Cultural, diferentes métodos e fontes de pesquisa foram empregados, entre eles a leitura de bibliografia correlata ao tema, periódicos produzidos contemporaneamente à existência do DOICODI, fotografias aéreas, vistorias in loco com a equipe técnica e com pessoas que foram detidas nas dependências, e da análise da documentação oficial produzida pelo Estado, além de relatórios produzidos pelo próprio órgão, e documentação inédita arquivada na Procuradoria do Patrimônio Imobiliário. 
O estudo durou cerca de um ano e meio visando compilar as informações necessárias para produzir um parecer consistente do ponto de vista da valoração daquele como um lugar de memória que reúne as condições necessárias para ser considerado patrimônio cultural. O tema é delicado e no ínterim do estudo, estava em andamento o trabalho das Comissões Nacional, Estadual e Municipal da Verdade, havendo clamor para que o Estado reconhecesse este e outros lugares de tortura, desaparecimento e morte como tal, implicando em reparação simbólica pela violação aos direitos humanos e o terrorismo de estado que teve lugar não só no Brasil, mas em toda a América Latina. Objetivou-se, com o estudo, apontar a história que permeia aquele lugar e que está diretamente ligada à História do país - quiçá da América do Sul ${ }^{16}$ - e demonstrar as razões que conduziram à indicação de tombamento.

A questão importante naquele momento foi compreender como e por que essa estrutura se instalou numa Delegacia já existente. E esse foi um dos embates importantes durante o estudo. A priori, a ocupação pela Oban - entre 1969 e setembro de 1970 - se deu no prédio da própria Delegacia e de um anexo construído ao fundo do terreno. Mas para obter informações mais consistentes, recorremos a documentos oficiais. Segundo informações do $1^{\circ}$ Cartório de Registros de Imóveis da Capital, o terreno de propriedade da Fazenda do Estado de São Paulo é fruto da desapropriação de três lotes a partir do Decreto 36.628/1960, que tratou da necessidade de ocupar a área de $2.858 .40 \mathrm{~m} 2$ para "a instalação da Delegacia de Polícia de Vila Mariana". Foram apresentadas pelo oficial três transcrições que dão conta de delimitar o terreno em questão; são elas: transcrição 53.470 de 30/09/1963, 65.328 de 16/02/1970 e 74.147 de 29/06/1972. Chamam a atenção as datas em que as duas últimas transcrições foram feitas, período em que a Oban já havia sido criada.

Recorreu-se, então, à pesquisa junto à Prefeitura, para identificação de plantas de construção, mas nada foi localizado. O uso do recurso de fotografias aéreas foi necessário porque tampouco a Polícia Civil as possuía. Foram utilizados mapeamentos aéreos das décadas de 1930, 1950 e aerofotografias de 1958, 1962, 1968, 1973 e 1977.

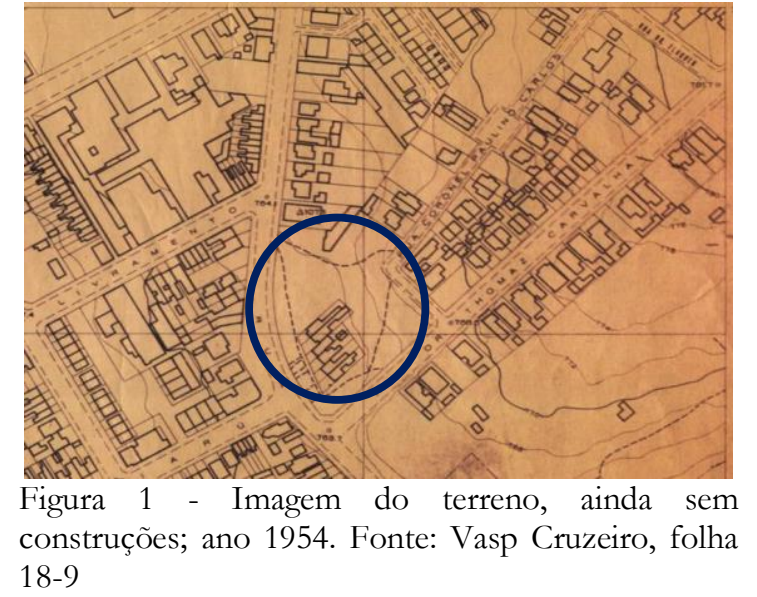

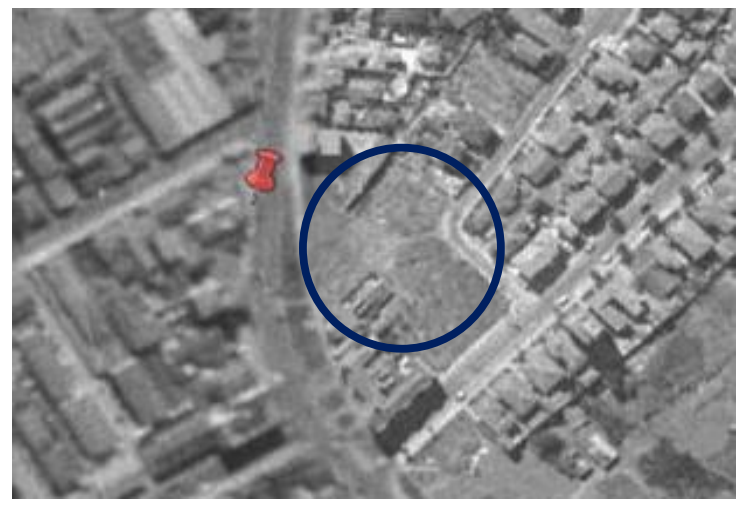

Figura 2 - Foto aérea datada de 1958, sem a construção de qualquer edifício. Fonte: Geoportal.

\footnotetext{
16 Fazemos esta referência porque durante a década de 1970 existiu um sistema de vigilância e repressão em cooperação entre Brasil, Argentina, Chile, Uruguai e Paraguai, denominado Operação Condor. Através dessa operação, os serviços de inteligência dos países do Cone Sul trocavam informações sobre as atividades de grupos e militantes revolucionários que atuavam fora das nações onde originalmente atuavam. Havia um intercâmbio com base nas embaixadas e nos serviços de inteligência. Esse sistema avançou para a realização de operações de prisão e tortura conjuntas e de troca de prisioneiros nos quatro países e o intercâmbio dessas pessoas entre regimes.
} 


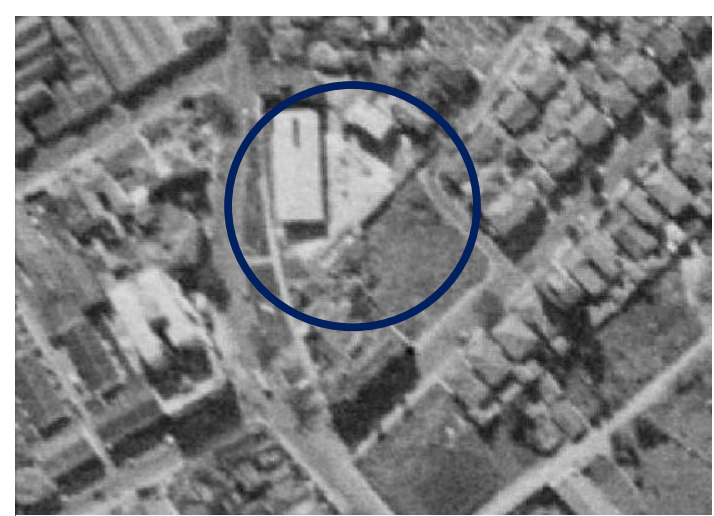

Figura 3 - Foto área do terreno, já com o prédio da Delegacia construído, e um edifício anexo. Ano: 1962. Foto: Base

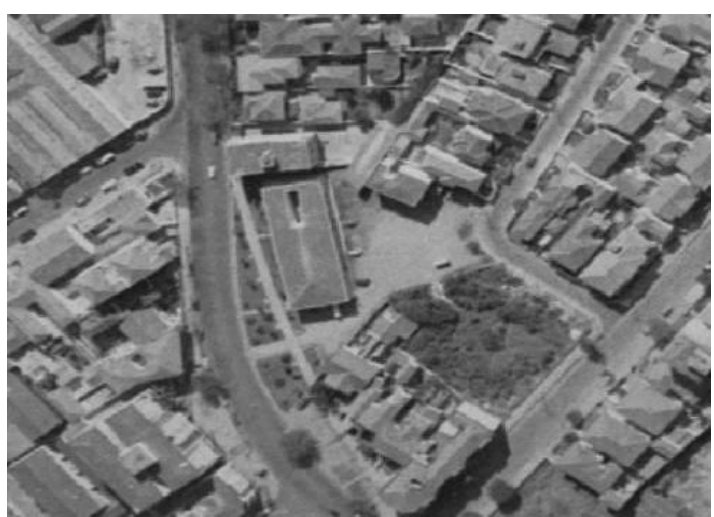

Figura 4 - Imagem aérea com o prédio da Delegacia e o utilizado pelo DOI CODI, em 1968. Foto: Base, 1:15.000, Foto 0481, OBRA-127A

Algumas observações são possíveis a partir das imagens aéreas: até 1958, nada havia construído na área. Em 1962, já existe o prédio da Delegacia e um anexo; e entre 1962 e 1968, apenas uma pequena construção latitudinal foi realizada, à esquerda do prédio anexo; observa-se também o prolongamento do estacionamento para sudeste do terreno.

Nas imagens a seguir, de 1973 e 1977 respectivamente, é possível constatar a ocupação plena do terreno. Percebe-se o crescimento de construções entre 1968 e 1973, quando outros dois edifícios e uma garagem foram construídos, ocupando a face do terreno voltado para a Rua Tomás de Carvalhal. Coincide com o período em que o DOI-CODI foi implantado e com a ampliação de prédios para o serviço. Na imagem aérea de 1973, nota-se a colocação de um portão entre o prédio da delegacia e seu vizinho, instalado por conta da fuga de um preso do DOI-CODI, segundo relatos de ex-presos.

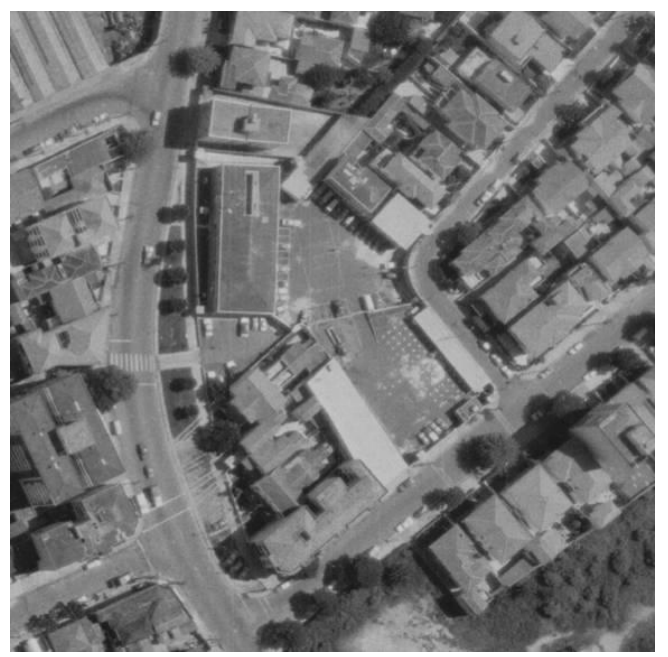

Figura 5 - Imagem aérea já com as construções do DOI CODI erigidas com entrada pela Tomás de Carvalhal, em Fev.1973. Foto: BASE S.A. 1:8.000, Foto 5488, OBRA-204.

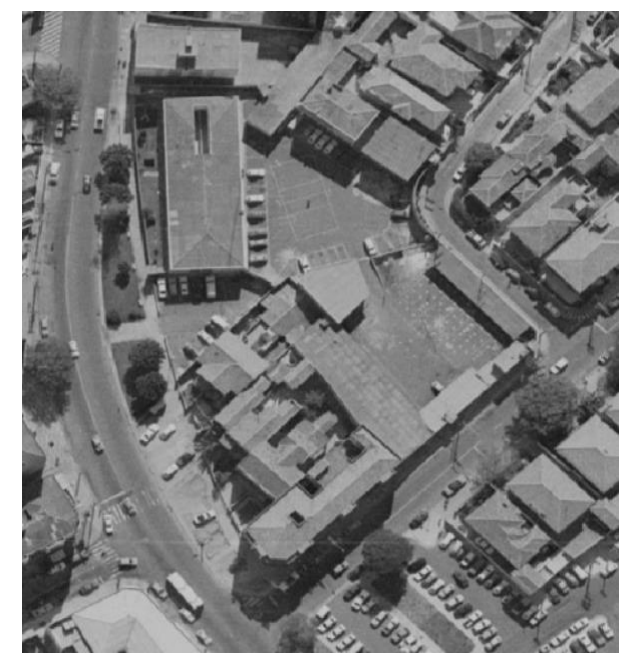

Figura 6 - Imagem aérea de 1977, com todas as edificações concluídas. Foto: BASE S.A. 1:8.000,Foto 2291, OBRA-292

Entre 1973 e 1977 é possível identificar a última grande obra de construção, uma área no meio do terreno utilizada como oficina mecânica. A partir de documentação cedida por um policial, identificamos que havia processo aberto na Procuradoria do Patrimônio Imobiliário e na 
Procuradoria Geral do Estado que tratavam da cessão do prédio do Estado de São Paulo para o II Exército. Uma vez consultados e confrontados com a bibliografia e com fotografias aéreas, as respostas começaram a surgir.

Como já tratado, a Oban se instalou nas dependências da $36^{a}$ Delegacia de Polícia e por isso contava com condições improvisadas e precárias. Acredita-se que institucionalização do órgão em 1970 resultou em benefícios para este: o efetivo foi ampliado de 116 servidores para 300 ${ }^{17}$, aumento na quantidade de armamentos, munições e viaturas fornecidas pelo Ministério do Exército, implantação de moderno sistema de comunicação. Todavia, não é a informação que Ustra apresenta em seu livro "Rompendo o silêncio"; de acordo com seu relato, quando ele assumiu o comando em setembro de 1970, a situação era a seguinte:

“As nossas viaturas eram poucas. Quatro C-14 emprestadas e dois Volks cedidos por uma Autarquia. O nosso serviço de comunicações, também, deixava muito a desejar. Um rádio em cada C-14, emprestados pela Polícia Militar. A nossa rede-rádio era a mesma da PM. Quanto ao armamento a situação era pior, os elementos da Polícia Militar traziam o armamento da PM. Nós, do Exército e o pessoal da Polícia Civil, usávamos as nossas armas particulares. A munição insuficiente. A segurança das instalações era precaríssima. A guarda externa, ostensiva, estava a cargo de um Destacamento da Polícia Militar, tendo como armamento as velhas metralhadoras INA, que funcionavam mal". ${ }^{18}$

Fica claro que Ustra quer demonstrar a situação do órgão quando assumiu o seu comando para compará-la com as ações que empreendeu para melhorá-lo; foi na sua "gestão" que ampliações passaram a ser feitas para abrigar a estrutura do órgão. De acordo com o Jornal do Brasil de 23/01/1976:

“Antes, a Oban funcionava em um prédio acanhado na Rua Tutoia, com entrada pelo $36^{\circ}$ Distrito Policial. Com a ampliação das atividades e a criação do DOI-CODI, as dependências também se ampliaram, construindo-se edificações num terreno de propriedade do Governo até atingir a Rua Thomás Carvalhal. A nova frente passou a levar o número 1030, entrada oficial para o Destacamento de Operações e Informações, do Centro de Operações de Defesa Interna". ${ }^{19}$

Com a intervenção de Ustra, solicitando a melhoria nas instalações do órgão, o DOI-CODI de São Paulo se organizou física e economicamente. O relato de Ustra dá a dimensão da aplicação de recursos do Estado em instalações do Exército, configurando, por si só, algo pouco comum na administração pública. Além disso, descreve cada um dos edifícios presentes no terreno e como cada um foi construído e ocupado.

"Mediante entendimentos entre o Comando do II Exército e o Governo do Estado, foram cedidas ao DOI $\mathbf{5 0 \%}$ das dependências do $36 .^{\circ} \mathrm{DP}$, inclusive toda a carceragem. Com os recursos recebidos do Governo do Estado, foi construído um prédio de dois andares, reformadas e adaptadas todas as nossas instalações. Construímos alojamentos para o pessoal de serviço, salas de interrogatório, garagens, oficina mecânica e melhoramos as instalações para os presos. Foram edificados muros mais altos e instaladas guaritas bem elevadas para os sentinelas. O combustível era quase totalmente fornecido pela Secretaria

\footnotetext{
${ }^{17}$ Essa informação, presente na tese de Mariana Joffily difere da apresentada por Carlos Alberto Brilhante Ustra, que afirma ser o DOI CODI de São Paulo "o de maior efetivo com cerca de 250 homens. Destes, 40 eram do Exército, sendo 10 oficiais, 25 sargentos e 5 cabos com estabilidade (profissionais) (...)". Os demais eram "os bravos e competentes membros das Polícias Civil e Militar”. USTRA, Carlos Alberto Brilhante. Rompendo o silêncio. Edição Digital, 1987, p.68.

18 Ibidem, p.71.

19 O prédio cinza do Bairro Paraíso. Jornal do Brasil, 23 jan. 1973, p.12. Disponível em http:/ / news.google.com/newspapers?nid=0qX8s2k1IRwC\&dat=19760123\&printsec $=$ frontpage \&hl=pt-BR, acessado em 28 jan. 2013.
} 
de Segurança Pública (SSP). Do Ministério do Exército recebemos armamento, munição, viaturas, pneus, peças sobressalentes, um moderno Sistema de Comunicações Rádio, bem como verbas adequadas para o pagamento de telefones, compra de material de expediente, arquivos, máquinas de escrever, copiadoras etc. O nosso efetivo foi bastante aumentado, chegando a atingir 250 homens. Moças da Polícia Feminina e da Polícia Civil foram requisitadas, assim como mecânicos, datilógrafos, operadores de rádio etc." 20

Apontamos aqui duas questões: o relato de Ustra confirma a versão de que as instalações para abrigar a Oban na Rua Tutoia foram pagas pelo Governo do Estado de São Paulo, sob o comando de Laudo Natel. ${ }^{21}$ Esse financiamento de obras para o Exército com verbas do Estado e do Município de São Paulo não foram incomuns. O então Prefeito da Capital Paulo Maluf destinou cerca de NCr $\$ 140.000,00$ para “(...)atender às despesas com a execução do muro de concreto ao longo da divisa do Quartel general do II Exército(...)”. ${ }^{22}$

E a segunda é que a estrutura descrita por Ustra coincide com a que se encontra erigida até os dias atuais, com poucas alterações, conforme verificado em vistoria. Além disso, o então Major afirma categoricamente ter utilizado $50 \%$ das instalações da delegacia, inclusive toda a carceragem. Esse é um relato importantíssimo, porque o Delegado titular, em 2012, afirmou que “(...) O DOI-CODI nunca funcionou em instalação desta distrital”; ${ }^{23}$ essa afirmação foi objeto de discussão entre ex-presos políticos em visita às instalações e o Delegado, que continuou a negar, mesmo quando confrontado com o testemunho de pessoas que ali ficaram detidas.

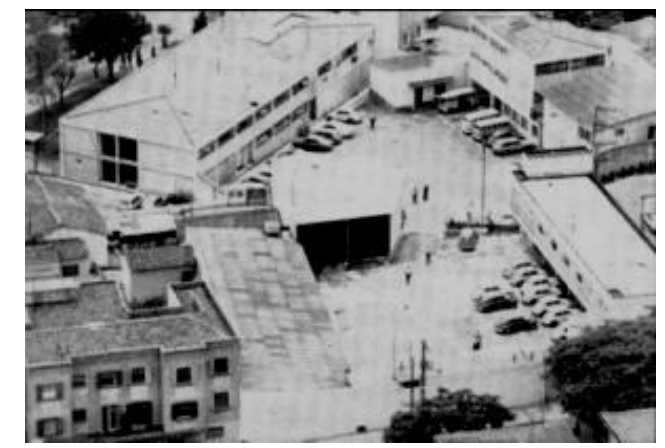

Figura 7 - Fotografia da década de 1970 que mostra os prédios do DOI-CODI. Foto: Sergio Sade.

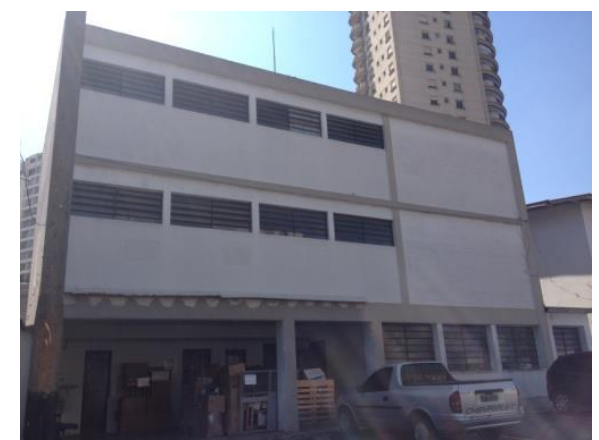

Figura 8 - Edifício de interrogatório e tortura. Foto: Deborah Neves, 2018

\footnotetext{
${ }^{20}$ USTRA, op. cit, p.75. Vale a observação oficial de que no cadastro de imóveis da Prefeitura de São Paulo, não consta nenhum contribuinte cadastrado no endereço Rua Tomás de Carvalhal, 1030. Isso porque, antes da construção do muro, o terreno era único, com entrada pela Rua Tutoia.

21 GASPARI, Elio. A ditadura escancarada. Companhia das Letras, São Paulo, 2002.

22 PREFEITURA DE SÃO PAULO. Lei nº7.372 de 20 de outubro de 1969. Autoriza abertura de crédito adicional e dá outras providências. Ver também PREFEITURA DE SÃO PAULO. Lei no 7.407 de 30 de dezembro de 1969. Autoriza abertura de crédito adicional e dá outras providências.

${ }^{23}$ NILSSON, Marcio de Castro. Despacho 1270/12, em: CONDEPHAAT. Processo 66578/2012, vol. II, fl.321.
} 


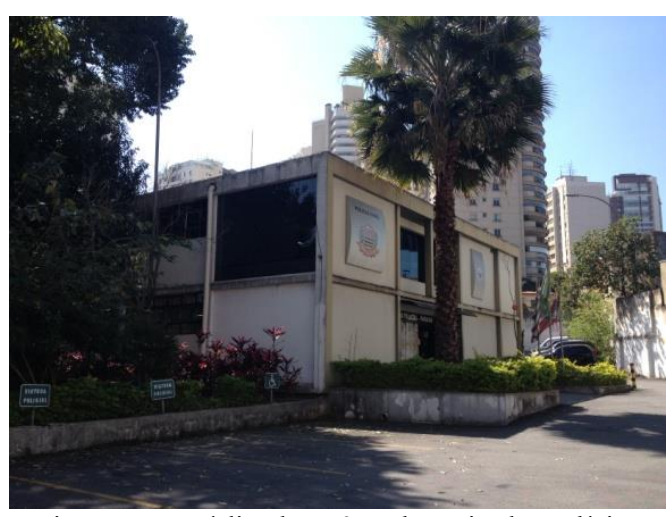

Figura 9 - Prédio da $36^{a}$ Delegacia de Polícia. Foto: Deborah Neves, 2017.

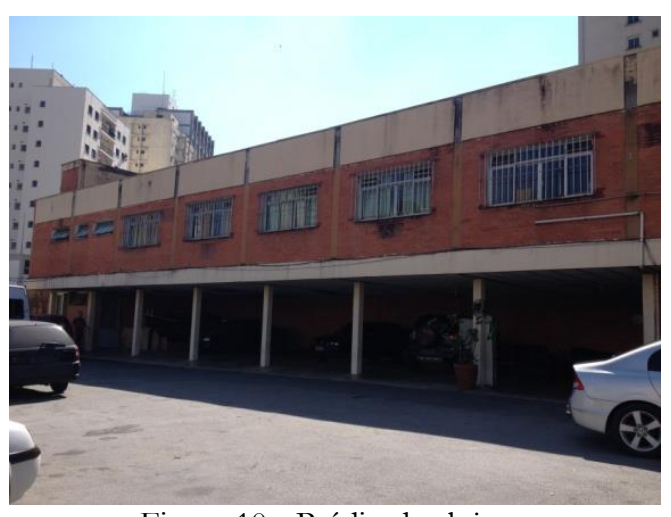

Figura 10 - Prédio de alojamento. Foto: Deborah Neves, 2017.

A documentação oficial não relacionada ao patrimônio ainda trouxe mais elementos para o estudo de tombamento. Ao longo dos meses de pesquisa, foi identificado que o então Governador Paulo Maluf, publicou um Decreto em $1979^{24}$ cedendo o uso de $1516,97 \mathrm{~m}^{2}$ ao II Exército, ou seja, não a totalidade do imóvel, mas apenas a parte cuja entrada se dá pela Rua Tomás de Carvalhal; entretanto, é sabido que além desta porção do terreno, tanto as dependências da $36^{a}$ DP quanto os outros dois edifícios do fundo também estavam sob o uso do II Exército. Além disso, a data de publicação do Decreto também chamou atenção: por que, quando o DOI-CODI já não tinha mais o mesmo papel nas forças de repressão e o país caminhava para uma abertura política (1979), o terreno foi oficialmente cedido ao II Exército?

A análise de documentos oficiais inéditos - cujo acesso foi possibilitado pela cessão de um documento por parte de um investigador de Polícia à UPPH - levou à identificação que as transcrições presentes na Certidão Imobiliária referente ao terreno onde foi construída a delegacia foram feitas em cartório apenas na década de 1970 - embora as decisões judiciais datassem de 1963 - porque nesse período houve a necessidade de identificar o imóvel e suas benfeitorias a fim de permitir a cessão do uso de parte do terreno ao Exército. Além de as transcrições serem posteriores, identificaram-se algumas falhas em procedimentos comuns para construções e ampliações. A primeira é a ausência de uma matrícula específica em Cartório unificando os três terrenos e certificando a propriedade ao Governo do Estado de São Paulo. A segunda é a inexistência de plantas e projetos dos edifícios erigidos após a construção original. Foi justamente a ausência desses documentos que criou uma situação insólita, que só foi possível conhecer a partir do acesso aos documentos sob a guarda da Procuradoria do Patrimônio Imobiliário (PPI) do Estado de São Paulo.

O processo PPI 47943/71 foi aberto após o Coronel Mário de Souza Pinto expedir um ofício datado de 25/03/1971, solicitando à Procuradoria do Patrimônio Imobiliário a permissão de uso a título precário de parte do terreno da $36^{a}$ Delegacia. Em resposta, o Delegado Paschoal Mantecca afirmou que o terreno já estava sendo utilizado pelo DOI-CODI - e de fato, já o estava desde 1969. Em 25/06/1971, o Diretor Geral de Polícia afirmou que não se opunha à permissão de uso, assim como o Secretário de Segurança Pública Gen. Sérvulo Mota Lima.

Para concretizar a cessão, foi realizada uma vistoria em 28/07/1971, realizada pelo engenheiro Antonio Marcos Alves Ribeiro, que fez a medição apenas do terreno, ignorando as construções. Essa omissão na descrição fez com que o "Termo De Permissão de Uso de Próprio Estadual, a Título Precário" assinado em 03/11/1971 trouxesse a informação de que a ocupação ocorreria em "um terreno, sem benfeitorias (...) completamente desocupado (...) no qual poderá efetuar as

${ }^{24}$ GOVERNO DO ESTAdO DE SÃO PAULO. Decreto no 13.757 de 09 de agosto de 1979. Autoriza a Fazenda do Estado a permitir o uso a título precário, em favor do Ministério do Exército, de imóvel que especifica. 
benfeitorias necessárias ao bom aproveitamento do imóvel". ${ }^{25} \mathrm{Na}$ verdade é sabido que as construções já tinham sido empreendidas, conforme se observa nas imagens de satélite. O Processo contém croquis de utilização do terreno pelo II Exército, não constando desenho das edificações.

Em 1977, uma junta de Procuradores da PPI entendeu que a cessão ocorreu de maneira incorreta e sugeriu a declaração de insubsistência do termo e regularização da cessão por meio de um Decreto; para isso seria necessária realização de vistoria para que houvesse a descrição do que exatamente estava sendo cedido. De acordo com informações constantes do processo, algumas solicitações de vistoria aos edifícios foram feitas, sem sucesso, no entanto. Em junho de 1979, portanto 10 anos depois do início efetivo do uso, o Eng. Edison Lemes da Silva relata sua tentativa de vistoria afirmando que tentou entrar o imóvel por três vezes e em nenhuma obteve êxito.

"Lá estive por três vezes, não podendo por duas vezes, por motivos imperiosos e alheios à minha vontade, ser atendido, pelas razões que passo expor: Na primeira vez, havia falecido sua Exa. Sr. General Comandante da $2^{a}$ Região Militar, e os serviços internos estavam suspensos e as dignas autoridades militares, de quem eu deveria obter informações para instruir o presente processo PPI, encontravam-se ausentes, pelos motivos já expostos.

$\mathrm{Na}$ segunda vez, que lá estive, era uma quarta-feira, período da tarde, e nas quartas feiras no período da tarde, os trabalhos internos burocráticos, nas guarnições militares, só funcionam no período da manhã, razões pertinentes ao regime interno dos serviços militares. Na terceira vez que lá estive, fui atendido, com as maiores das atenções, pelo Sr. Tenente Coronel Aldo, Chefe da Seção

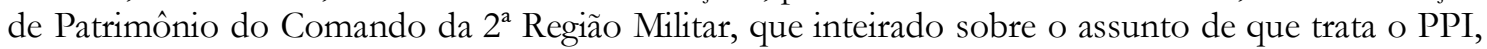
encaminhou-me à presença do Sr. Major Paulo Mauer Storelli, que respondia no momento, pelo Sr. Coronel Alexander, assistente do Sr. General Comandante do $2^{\circ}$ Exército; sua senhoria, inteirado do assunto, não pode no momento encaminhar a presença do Sr. General Comandante, pois o mesmo se encontrava em Caçapava, no Regimento de Infantaria, por ser dia da comemoração da referida Arma do Exército. Entretanto, o Sr. Major Paulo Mayer Storelli, encaminhou-me à presença do Sr. Coronel Wladimir Nogueira, Chefe da IV Seção do $2^{\circ}$ Exército, que também, por sua vez, desejava me apresentar a Sua Exa. o Sr. General do Exército José Fragomeni, para que o mesmo decidisse sobre o respeitável despacho de fls. $18,48 \mathrm{v}^{\circ}$ e 49 do presente processo. Entretanto, na audiência mantida com o Sr. Coronel Wladimir Nogueira, responsável pela Chefia IV Seção do $2^{\circ}$ Exército, o mesmo informou, que o II Exército, têm necessidade de continuar ocupando a parte do imóvel que pertence na sua totalidade ao Estado, e onde está instalado a 36a Delegacia de Polícia, de Vila Mariana, também. A parte do terreno cedido a título precário ao II Exército, (...) está situado na esquina das ruas Thomaz Carvalhal e Coronel Paulino Carlos. Nesse local encontra-se instalado o DOI/CODI do II Exército; (Centro de Operações de Defesa Interna)." 26

Identificada a necessidade de continuação do uso pelo II Exército, a recomendação foi de que deveria ser "convalidada a ocupação, por ato governamental sob a forma de permissão a título precário". De maneira bastante célere - entre 06/06/1979 e 09/08/1979 - a situação da cessão foi regularizada, após o Governador Paulo Maluf assinar o Decreto 13.757/1979, cedendo formalmente o uso ao II Exército, de um terreno sem benfeitorias, ainda desconsiderando as construções realizadas. Mas foi apenas em 15/09/1981, dois anos após a publicação do Decreto, que o termo de acordo entre as partes foi assinado e a única planta do local elaborada, considerando apenas parte dos edifícios construídos para o DOI-CODI. A extinção do DOICODI ocorreu em 1983, e não há informações de quando o prédio foi desocupado pelo II Exército. A devolução formal ocorreu apenas em 1991.

\footnotetext{
25 PROCURADORIA DO PATRIMÔNIO IMOBILIÁRIO. Processo 47943/71, p.37-38.

26 SILVA. Edilson Lemes da. "Relatório de vistoria". In: SÃO PAULO (GOVERNO) PROCURADORIA DO PATRIMÔNIO IMOBILIÁRIO. Processo 47943/71. São Paulo: 1971.
} 
O que se pode inferir da análise da documentação é a clara colaboração do Estado de São Paulo com as atividades de repressão empreendidas pelo II Exército a ponto de ceder um terreno e parte das instalações oficiais de uma delegacia. Fato é que o imóvel continua pertencendo ao Governo do Estado de São Paulo, o que facilitou as vistorias da UPPH, sempre atendidas de imediato quando solicitadas à Polícia Civil, e que permitiram a elaboração das primeiras plantas do edifício de principal uso do DOI-CODI.

A primeira planta foi elaborada pela arquiteta Adda Alessandra Piva Ungaretti, da Unidade de Preservação do Patrimônio Histórico da Secretaria de Estado da Cultura, no âmbito do estudo de tombamento em 2013, com base nas vistorias realizadas no edifício e contando com a participação efetiva de pessoas que lá estiveram para apontar onde ficaram presos, onde foram torturados e o que funcionava em cada um dos locais.

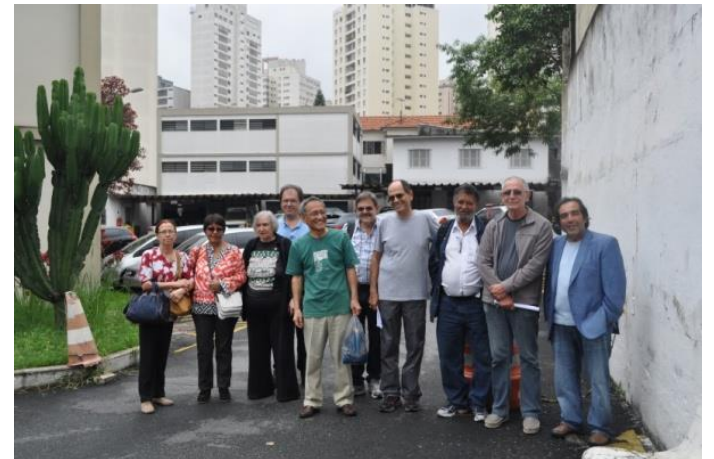

Figura 11 - Cleuzer Barros, Cida Santos, Elza Lobo, Ivan Seixas, André Ota, Maurice Politi, Carlos Russo, Carlos Licht, Manoel Cyrillo e Adriano Diogo. Foto: Deborah Neves, 08 abr. 2013

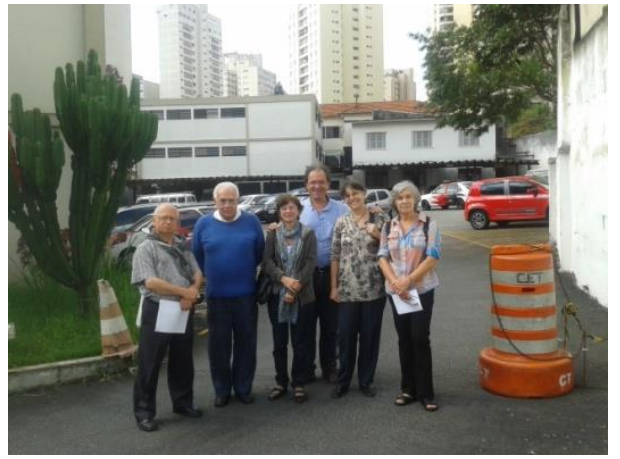

Figura 12 - Tullo Vigevani, Carlos Di Pietra, Cida Costa, Ivan Seixas, Janice Theodoro e Ana Maria Aratangy. Foto: Deborah Neves, 16 abr. 2013.

A presença de ex-presos, convidados a partir da contribuição das organizações que solicitaram o tombamento, foi indispensável para a compreensão do espaço. Eles foram divididos em turmas de pessoas detidas no mesmo ano - 1969 a 1975 - com o objetivo de classificar as impressões por período, já que é sabido - com a experiência de coletas de testemunhos sobre o DOPS e outros locais de detenção na América Latina, como a ESMA, por exemplo - que as instalações de locais de detenção eram alteradas com frequência. O momento das visitas foi bastante intenso, já que a maioria nunca havia retornado ao local, e todos se emocionaram. As reações foram diversas: houve aqueles que se calaram diante das lembranças, outros que falaram sem parar, outros falaram pouco, alguns não se lembraram de nada. Mas todos contribuíram com a reconstituição do espaço de maneira inegável. As figuras 11 e 12 apresentam parte dos grupos que fizeram as visitas em dois dias distintos, e o sentimento ali era o de estar contribuindo para a história e a memória do país, além de certa reparação moral em retornar ao local em condições muito diversas daquelas em que estiveram pela primeira vez.

As alterações que foram identificadas em vistorias, e também de acordo com o relato dos expresos, dão pistas de que a configuração do edifício foi bastante alterada ao longo do uso pelo próprio DOI-CODI, como após sua desocupação e restituição aos órgãos da Polícia Civil. Nesse sentido, supõe-se que as alterações produzidas durante o uso do DOI-CODI serviram tanto para adaptar o edifício às demandas quanto como para apagar eventuais vestígios das atividades ali praticadas. Por essa razão, o Estudo de Tombamento recomendou prospecções arquitetônicas em todo o edifício a fim de identificar as alterações às quais o edifício foi submetido. 

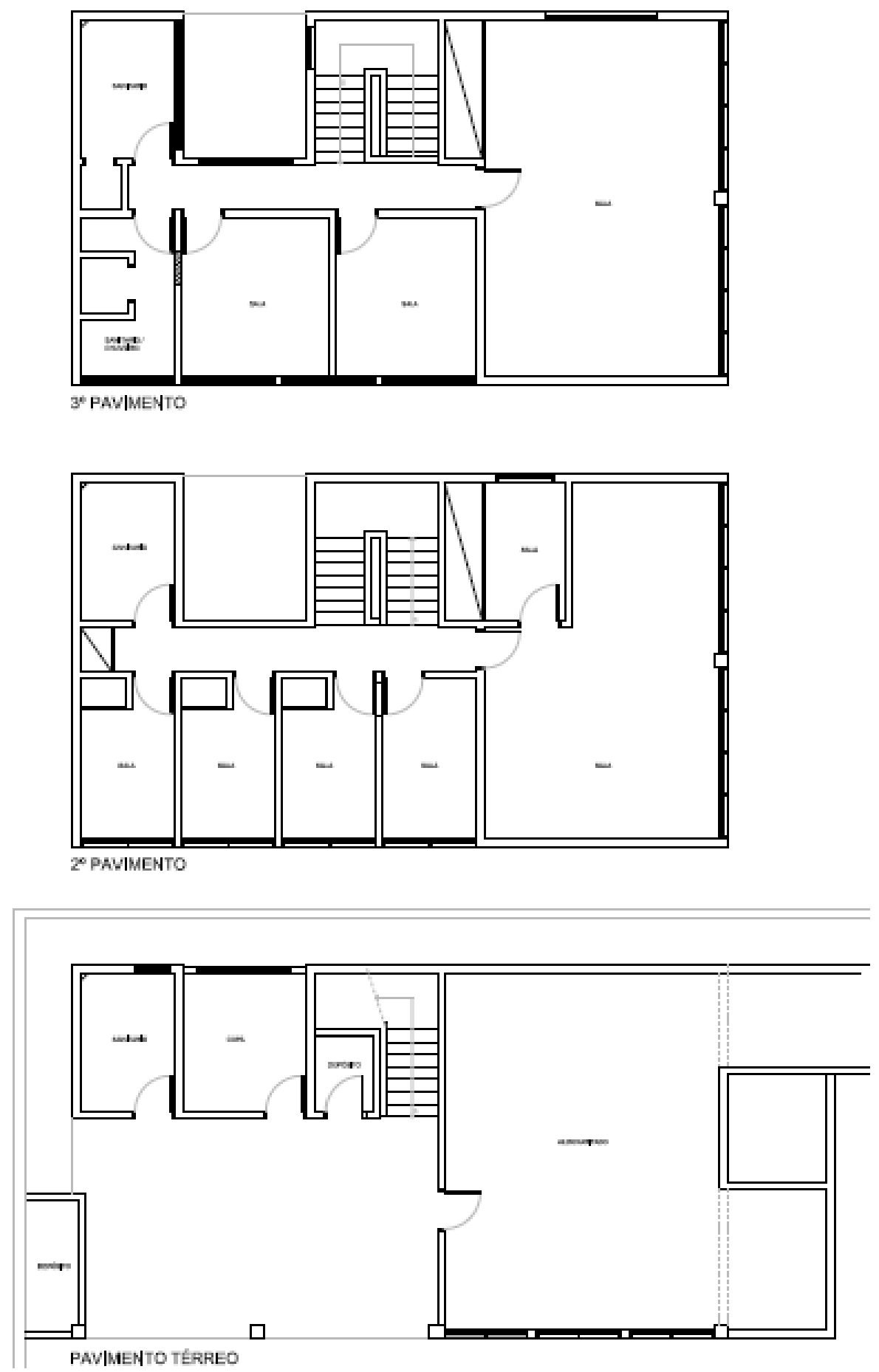

Figura 13 - Plantas dos 3 pavimentos elaborada após vistoria. Autoria: Adda Alessandra Piva Ungaretti, fev.2013.

A observação do edifício e as vistorias técnicas foram indispensáveis para compreender a dinâmica do espaço e a classificação da importância de preservação de cada um dos espaços. Uma das informações mais relevantes, que ainda resta sem resposta, é o local onde o jornalista Vladimir Herzog foi fotografado morto. A morte de Herzog em outubro de 1975, associada à morte do Tenente-Coronel da PM José Ferreira de Almeida (08/1975) e do operário metalúrgico Manoel Fiel Filho (01/1976) - todos presos e mortos no DOI-CODI, com laudo informando 
suicídio - foram determinantes para o aprofundamento de mudanças políticas que, depois, resultaram no fim da Ditadura. Os três foram interrogados pela mesma turma do órgão ${ }^{27}$.

A imagem de Herzog morto é bastante conhecida no Brasil e tinha como objetivo provar suicídio, e não assassinato. Mas o fato é que ela teve o efeito contrário, pois serviu como prova de que a foto foi uma montagem com o corpo já sem vida de Herzog. A morte de Herzog - que se apresentou voluntariamente após ser intimado a depor - serviu como estopim para mobilizações sociais que criaram um clima pouco favorável aos militares e contribuíram para a desestabilização da Ditadura, levando à destituição de comandantes do Exército.

Quem poderia fornecer informações precisas sobre o assunto é Silvaldo Leung Vieira, fotógrafo da Polícia Civil que retratou a imagem de Herzog enforcado. Vieira, que se auto-exilou nos Estados Unidos desde o fim da década de 1970 informou que "antes de chegar à sala onde estava o corpo, passei por vários corredores” e que “(...) não me deixaram circular livremente pela sala, como todo fotógrafo faz quando vai documentar uma morte. Não tive liberdade. Fiz aquela foto praticamente da porta (...)" ${ }^{\prime 28}$.

A Comissão Municipal da Verdade de São Paulo o convidou a visitar as instalações do DOICODI e prestar depoimento em maio de 2013. A oportunidade era única para tentar identificar onde a fotografia foi realizada. Porém, a Comissão não teve o cuidado de proteger Vieira e sua visita foi acompanhada por dezenas de pessoas, a maioria jornalistas, de modo que ele sentiu-se acuado e intimidado durante o percurso realizado nos prédios. Limitou-se a dizer que não se lembrava em qual dos edifícios realizou as fotos. Em seu depoimento, no dia seguinte, afirmou que:

"Só lembro que era noite e o acesso ao local, fácil. Fotografei da porta, não entrei. As pessoas que me levaram de carro não foram aquelas que subiram comigo. Abriram a porta, me mostraram. (Vi) o cadáver em frente da porta. Disseram: fotografa. Tirei três fotos com aberturas diferentes sem me mexer de onde estava e saí. Estranhei a posição. Pela posição dos pés, no chão. E a blindagem, de impedir outras fotos do local. Normalmente tínhamos liberdade de verificar o local em detalhes" ${ }^{\prime 2}$.

Considerando que a imagem é um documento histórico, por ser talvez a única fotografia de um cadáver registrada no interior do edifício e produzido para justificar a morte do jornalista, durante o Estudo de Tombamento foram feitas análises para tentar identificar em qual local o registro foi feito. E o resultado foi inédito até então. A partir das vistorias realizadas, assumiu-se a hipótese que a fotografia foi feita dentro do edifício principal do DOI-CODI. Observemos as imagens a seguir:

\footnotetext{
${ }^{27}$ SOUZA, Percival de. Autópsia do medo: vida e morte do Delegado Sergio Paranhos Fleury. São Paulo: Globo, 2000, p. 208.

${ }^{28}$ Depoimento de Silvaldo Leung Vieira em entrevista. FERRAZ, Lucas. O instante decisivo. A Folha localizon o fotógrafo do cadáver de Herzog. Folha de São Paulo. Caderno Ilustríssima, p.6, 05 fev. 2012.

29 Depoimento de Silvaldo Leung Vieira. CAMARA MUNICIPAL DE SÃO PAULO. Comissão Municipal da Verdade Vladimir Herzog. Relatório. Capítulo VI - Somos Todos Vlado. São Paulo, 2015. Disponível em http://www.saopaulo.sp.leg.br/livrocomissaodaverdade/, acessado em 10 set. 2018.
} 


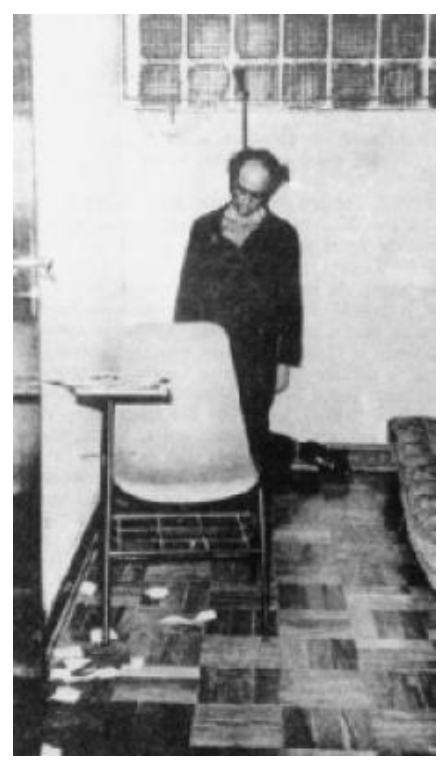

Figura 14 - Foto de Silvaldo Leung Vieira, que retratou a farsa do suicídio de Herzog.

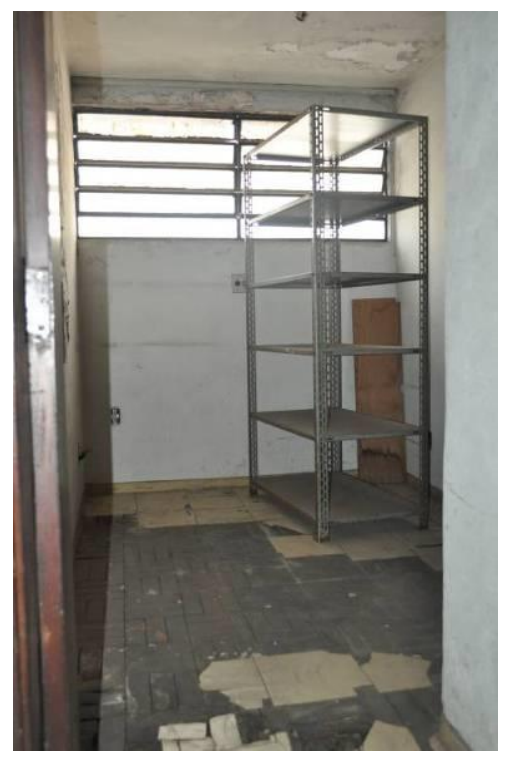

Figura 15 - Uma das salas do edifício do DOICODI, muito semelhante à da foto de Herzog. Foto: Deborah Neves, set.2012.

A semelhança de pisos e envasaduras de janela é impressionante. Identificou-se em vistoria que a envasadura foi modificada - em alguns casos, aumentada e, em outros, diminuída em sua largura - e esquadrias foram trocadas. Por essa razão, há indícios de que a montagem da cena da foto de divulgação da morte de Herzog foi feita nas dependências do edifício principal do DOI-CODI. Existem informações que apontam uma sala nas dependências da delegacia como sendo o local onde a farsa foi montada, mas a indisponibilidade de imagens para que se possa comparar, inviabiliza a afirmação categórica, uma vez que a delegacia passou por uma profunda reforma que a descaracterizou substancialmente. A Comissão Nacional da Verdade (CNV) chegou a conclusão semelhante, porém, apenas em dezembro de 2014, um ano e meio depois da conclusão do Estudo de Tombamento, finalizado em abril de 2013. Uma vistoria foi realizada pela CNV em 27/11/2013 - após a finalização dos estudos de tombamento -, com apenas três pessoas que ali ficaram detidas. Na ocasião, havia mais autoridades de Estado que ex-presos ${ }^{30}$. Os peritos que vistoriaram o local produziram uma planta semelhante àquela já produzida pela UPPH, e nunca contataram ou consultaram o processo finalizado, resultando na elaboração de um documento sobre o local bastante simplificado. O destaque fica para a ausência de citação ou referências ao Estudo de Tombamento no Relatório Final da CNV, que apresentou comparação da fotografia de Herzog e da sala de torturas semelhante à apresentada no Parecer Técnico da UPPH ${ }^{31}$.

\section{O tombamento e as perspectivas futuras.}

O Parecer Técnico reuniu todas as informações coletadas durante o estudo de tombamento e se valeu de algumas premissas: o valor do imóvel é histórico e nele se assenta, afinal, a materialidade é apenas um suporte no qual se imprime o valor social, sentidos e significados. Aliado a isso, pela primeira vez, recomendava-se a adoção de instrumento multinacional editado pelas Altas Autoridades em Direitos Humanos do Mercosul como orientador da preservação do bem. Com isso, passou-se a compreender a materialidade daquele local como um documento histórico e como evidência do cometimento de crimes contra a dignidade humana. Destacou, ainda, o apoio

\footnotetext{
${ }^{30}$ BRASIL. Comissão Nacional da Verdade. Relatório Preliminar sobre a visita ao DOI-CODI de São Paulo, Capital, atual $36^{\mathrm{a}}$ Delegacia de Polícia Civil. Brasília, 2013. Disponível em http://cnv.memoriasreveladas.gov.br/images/documentos/Capitulo15/Nota\%2042\%2043\%20-

$\% 20$ Relatorio $\% 20$ Preliminar $\% 20$ visita $\% 20$ DOICODI $\% 20-\% 20$ Sao $\% 20$ Paulo\%20-\%2027112013.pdf, acessado em 08 set. 2018.

${ }^{31}$ BRASIL. Comissão Nacional da Verdade. Relatório. Capítulo 15, p.759
} 
ao tombamento por parte do Ministério Público Federal e a recomendação no mesmo sentido da Comissão Nacional da Verdade, que se manifestaram por meio de ofício.

A proposta de preservação foi construída considerando experiências do exterior, notadamente a Alemanha - que possui larga e diversa experiência tanto na preservação de lugares relacionados ao nazismo como também de uso -, mas especialmente a experiência do Casino de Oficiales, localizado no complexo de edifícios que abrigou a ESMA, hoje convertido em Espacio Memoria. A referência argentina foi a predominante porque, além de ser mais próximo temporal e historicamente, se pautou por amplo debate na sociedade mais contemporaneamente. Além disso, a semelhança de uso e ocupação do espaço e as condições materiais do edifício também são bastante similares.

Argumentava-se ainda que se tratava de momento político adequado para o tombamento desta natureza, afinal, completava-se 50 anos do Golpe, o governo Federal - sob o comando da Presidenta Dilma Rousseff, militante de esquerda que foi presa e brutalmente torturada - estava empenhado, por meio da CNV, em produzir um acerto de contas do Estado com a sociedade, o tema era recorrente na imprensa e a elucidação de crimes gerava expectativa social.

Dessa forma, foi apresentado o estudo acompanhado de minuta de Resolução que reconhecia as instalações da Oban/Doi-Codi como lugar de memória da repressão e da resistência à ditadura, de institucionalização do terrorismo de Estado, de violação de Direitos Humanos, testemunho material da história política recente, suporte físico da repressão e da resistência e que o tombamento atenderia às políticas de memória e reparação instituídas pelo Estado contemporâneo, notadamente ao Plano Nacional de Direitos Humanos-3 e às legislações estadual (Lei Estadual $n^{\circ}$ 7.576/91 e 10.726/2001). Recomendou, como diretriz, o tombamento integral do edifício de interrogatórios, da parte da antiga carceragem e volume da $36^{a}$ Delegacia e o tombamento apenas da face externa dos demais edifícios, além das guaritas - que comprovam a construção militar no local - e área non aedificandi no pátio de veículos, indicado por ex-presos como o primeiro local de torturas, logo ao desembarcar das viaturas. Não há dúvidas de que a principal inovação deste tombamento foi justamente a inclusão da diretriz de intervenção apontada no Inciso II do Artigo $3^{\circ}$, que se refere ao prédio de interrogatórios. Nele, estabeleceuse que a “(...) intervenção física nas áreas internas deve ser precedida de avaliação prospectiva e estratigráfica de paredes e pisos, a fim de detectar elementos que possam vincular o espaço ao cometimento de crimes e à permanência de detidos" ${ }^{\$ 32}$. O objetivo era atender a recomendação do IPPDH de compreensão do espaço como evidência criminal, que futuramente pode ser utilizado em casos judiciais como prova ${ }^{33}$. O objetivo era evitar que houvesse repetição dos equívocos que ocorreram no processo de reocupação do Antigo Dops, cujas evidências de ocupação pelo órgão e por presos foram suprimidas em reforma empreendida entre 1999 e 2002.

O voto ficou sob a responsabilidade da Profa. Dra. Silvana Rubino, antropóloga e historiadora atuante na Unicamp. Nele, Rubino reconhece a ausência de importância plástico-arquitetônica do edifício, mas salienta que “(...) os eventos que lá ocorreram são indissociáveis da materialidade (...)" e, por isso, mesmo que "sem valor arquitetônico e eivado de lembranças funestas, o prédio cinza da rua Tutóia deve, e é este o argumento desse parecer, ser tombado. O edifício atravessou o tempo, a redemocratização. Suporte de memórias difíceis, não devemos dele prescindir”34. Ressaltou a opinião técnica de que esse tombamento poderia inspirar outros órgãos estaduais do Brasil a fazer o mesmo com seus edifícios que remetem a tais memórias. Finaliza corroborando com o pedido das entidades de Direitos Humanos solicitantes do tombamento e da UPPH de

\footnotetext{
${ }^{32}$ NEVES, Deborah Regina Leal. Parecer Técnico UPPH n ${ }^{\circ}$ GEI-256-2012, in: CONDEPHAAT. Processo $66578 / 2012$.

${ }^{33}$ INSTITUTO DE POLÍTICAS PÚBLICAS EM DIREITOS HUMANOS DO MERCOSUL (IPPDH).

Diretrizes para a preservação de lugares de Memória, aprovadas pelas Altas Autoridades de Derechos Humanos y Cancillerías del Mercosur y Estado Associados. Argentina, 2012.

${ }^{34}$ RUBINO, Silvana Barbosa. Voto. CONDEPHAAT. Processo 66578/2012, pp. 646-649.
} 
que o lugar deve ser convertido em espaço de conhecimento, reflexão e memória sobre o período, uma vez que o tombamento é apenas a medida inicial, mas não a única, para a correta fruição pública do espaço.

Levado ao plenário na Sessão Ordinária de 27 de Janeiro de 2014, contando com a presença do Secretário da Cultura Marcelo Mattos Araújo, o prédio teve tombamento decidido por unanimidade, sem debate por parte dos membros do Condephaat, não se sabe se por absoluta concordância com a proposta, ou se por certa perplexidade em ter contato com um tema tão pesaroso no campo do patrimônio, que costuma guardar espaço para memórias "felizes". $\mathrm{Na}$ ocasião, estavam presentes de Ivan Seixas - autor do pedido - e do Deputado Estadual Adriano Diogo (Presidente da Comissão Estadual da Verdade Rubens Paiva), a quem foi concedida a palavra. Seixas expressou sua emoção com o tombamento, destacando a representatividade histórica do edifício e a importância para os trabalhos da Comissão da Verdade. Diogo ressaltou a importância da retirada da delegacia para a implantação de um memorial no local ${ }^{35}$.

Esse é um dos raros casos que não teve apresentação de contestação por ocasião do tombamento, que foi formalizado pela resolução SC-25 de 12 de maio de 2014, colocando o estado de São Paulo na vanguarda da preservação de lugares de memória relacionados à ditadura, se antecipando às recomendações da Comissão Nacional da Verdade, apresentadas em dezembro de 2014. Não há dúvidas de que este é um caso paradigmático e importantíssimo para a história da preservação do patrimônio cultural e como uma das políticas reparatórias possíveis dentre as já conhecidas em casos de Justiça de Transição.

No entanto, quatro anos após o tombamento, ainda não há uso definido para o local. Após o tombamento, moradores do bairro de Vila Mariana organizaram um abaixo-assinado contendo em torno de 10 mil assinaturas contrários à retirada da Delegacia do local; não porque fossem contrários à instalação do memorial, mas por receio de não poderem mais contar com um equipamento de segurança pública no bairro. Era ano de eleição e as negociações para a desocupação foram paralisadas. Desde então, não houve mais avanços e não houve a conversão do edifício em espaço de memória.

No fim de março de 2018, um Grupo de Trabalho composto pela UPPH, pelo Ministério Público Federal, Ministério Público Estadual, Memorial da Resistência, Núcleo Memória, Instituto de Estudos da Violência de Estado, Laboratório de Arqueologia Pública (Unicamp), Centro de Antropologia e Arqueologia Forense (Unifesp), Programa de Pós-Graduação em Memória Social (UFPel) debateram formas de ocupar, ainda que paulatinamente, o espaço que serviu ao Doi-Codi, iniciando pelo prédio de interrogatório, que já está desocupado desde 2012. Um ofício do Secretário da Cultura foi enviado ao Secretário de Segurança Pública solicitando a cessão deste único prédio, como forma de instalar já imediatamente um equipamento de memória e para que se iniciem as pesquisas arqueológicas no edifício ${ }^{36}$. Até o momento da elaboração deste artigo, ainda não havia resposta ao pedido.

\section{Conclusão}

Os desafios da elaboração deste estudo reforçam a ideia de que o tombamento deve estar sempre em sintonia com o espírito do momento, não se restringindo a adotar soluções já conhecidas na preservação, porque, como anseio social, reflete a dinâmica da sociedade e de seus interesses e percepções. Além disso, evidencia que o tombamento é instrumento que se coaduna com a reparação simbólica a grupos historicamente perseguidos social e politicamente, e também um campo de disputas em permanente debate. Se em 2014 ele ocorreu de forma unânime pelo

\footnotetext{
${ }^{35}$ CONDEPHAAT. Ata 1735 da Sessão Ordinária realizada em 27-01-2014. Diário Oficial do Estado de São Paulo. Poder Executivo, Seção I. Secretaria da Cultura. 21 fev. 2014, p.49.

${ }^{36}$ Ofício GSSEC n³83-2018 em CONDEPHAAT. Processo 76327/2016.
} 
conselho e teve aceitação social, talvez atualmente, em 2018, ele fosse objeto de contestações por parte de grupos que insistem na tese do revisionismo sobre a ditadura, ou que preferem enaltecer torturadores. Nesse sentido, é importante destacar que o tombamento é apenas o primeiro passo dentro daquilo que deve se constituir como uma política pública mais ampla, articulada com outras instituições civis e de Estado; do contrário, o tombamento torna-se ação meramente declaratória, sem o efeito que se pretende atingir, que é o da identificação e valorização de memórias, sejam difíceis ou não.

Por ser um estudo pioneiro em sua forma e resultado, serve como um guia para outros tombamentos, sendo possível, com distanciamento, analisar os acertos e as lacunas, abrindo espaço para a adoção de novas medidas que visem a preservação e o uso desses espaços, impactando não só no trabalho de preservação do patrimônio, mas na colaboração do fortalecimento dos valores democráticos, que parecem estar sempre sob ameaça.

\section{Referências:}

AMARAL, Rita. "O tombamento de um terreiro de Candomblé em São Paulo", Comunicações do ISER n41, ISER, Rio de Janeiro, 1991. Disponível em http://axeileoba.com.br/arquivo/publicacoes/UrbanitasRitaAmaral_Site.pdf, acessado em 08 set. 2018.

BRASIL. COMISSÃO NACIONAL DA VERDADE. Relatório. Brasília: CNV, 2014.

BRASIL. Comissão Nacional da Verdade. Relatório Preliminar sobre a visita ao DOI-CODI de São Paulo, Capital, atual $36^{a}$ Delegacia de Polícia Civil. Brasília, 2013. Disponível em http:// cnv.memoriasreveladas.gov.br/images/documentos/Capitulo15/Nota $\% 2042 \% 2043 \%$ $20-\% 20$ Relatorio $\% 20$ Preliminar $\% 20$ visita $\% 20$ DOICODI $\% 20-\% 20 \mathrm{SaO} \% 20 \mathrm{Paulo} \% 20$ \%2027112013.pdf, acessado em 08 set. 2018.

BRASIL NUNCA MAIS. $3^{a}$ Edição. São Paulo: Editora Vozes, 1985.

CAMARA MUNICIPAL DE SÃO PAULO. Comissão Municipal da Verdade Vladimir Herrog. Relatório. Capítulo VI - Somos Todos Vlado. São Paulo, 2015. Disponível em http://www.saopaulo.sp.leg.br/livrocomissaodaverdade/, acessado em 10 set. 2018.

CONDEPHAAT. Processo 66578/2012.

CONDEPHAAT. Processo 76327/2016.

FERRAZ, Lucas. O instante decisivo. A Folha localizon o fotógrafo do cadáver de Herzog. Folha de São Paulo. Caderno Ilustríssima, p.6, 05 fev. 2012.

GASPARI, Elio. A ditadura escancarada. Companhia das Letras, São Paulo, 2002.

GOVERNO DO ESTADO DE SÃO PAULO. Decreto no 13.757 de 09 de agosto de 1979. Autoriza a Fazenda do Estado a permitir o uso a título precário, em favor do Ministério do Exército, de imóvel que especifica.

HUGGINS, Martha K. Polícia e política: relações Estados Unidos/América Latina. Trad. Lólio Lourenço de Oliveira. São Paulo: Ed. Cortez, 1998.

INSTITUTO DE POLÍTICAS PÚBLICAS EM DIREITOS HUMANOS DO MERCOSUL (IPPDH). Diretrizes para a preservação de lugares de Memória, aprovadas pelas Altas Autoridades de Derechos Humanos y Cancillerías del Mercosur y Estado Associados. Argentina, 2012.

JOFFILY, Mariana. No centro da engrenagem: os interrogatórios na Operação Bandeirante e no DOI de São Paulo. Tese (Doutorado em História Social). Faculdade de Filosofia, Letras e Ciências Humanas, Universidade de São Paulo, 2008.

KUSHNIR, Beatriz. Cães de Guarda. São Paulo: Boitempo, 2004

MARINS, Paulo César Garcez. "Do Luz Cultural ao Monumenta: sobre a opção pela escala monumental na preservação de uma área de São Paulo", em GAGLIARDI, Clarissa Rosa, et 
al. (coord.). Intervenções urbanas em Centros Históricos: casos da Itália e São Paulo em discussão. São Paulo: Educ/PUC, 2011.

NEVES, Deborah Regina Leal. A persistência do passado: memoriais e patrimônio da ditadura em São Paulo e Buenos Aires. São Paulo: Editora Alameda, 2018.

NEVES, Deborah Regina Leal. Parecer Técnico UPPH $n^{\circ}$ GEI-256-2012, in: CONDEPHAAT. Processo 66578/2012.

O prédio cinza do Bairro Paraíso. Jornal do Brasil, 23 jan. 1973, p.12. Disponível em http:/ / news.google.com/newspapers?nid=0qX8s2k1IRwC\&dat $=19760123 \&$ printsec $=$ frontp age\&hl=pt-BR, acessado em 28 jan. 2013.

PEREIRA, Freddie Perdigão. O Destacamento de Operações de Informacõos (DOI) no EB - Histórico papel no combate à subversão: situação atual e perspectivas. Escola de Comando e Estado-Maior do Exército, 1978.

PREFEITURA DE SÃO PAULO. Lei nº7.372 de 20 de outubro de 1969. Autoriza abertura de crédito adicional e dá outras providências. Ver também PREFEITURA DE SÃO PAULO. Lei $n^{\circ} 7.407$ de 30 de dezembro de 1969. Autoriza abertura de crédito adicional e dá outras providências.

PROCURADORIA DO PATRIMÔNIO IMOBILIÁRIO. Processo 47943/71

RODRIGUES, Marly. Imagens do passado. A instituição do patrimônio em São Paulo (1969-1987). São Paulo: Ed. UNESP; Imprensa Oficial; Condephaat; FAPESP, 2000.

RUBINO, Silvana Barbosa. Voto. CONDEPHAAT. Processo 66578/2012, pp. 646-649.

SCIFONI, Simone. A construção do patrimônio natural. Tese (Doutorado em Geografia). Faculdade de Filosofia, Letras e Ciências Humanas, Universidade de São Paulo. São Paulo, 2006.

SILVA. Edilson Lemes da. "Relatório de vistoria". In: SÃO PAULO (GOVERNO) PROCURADORIA DO PATRIMÔNIO IMOBILIÁRIO. Processo 47943/71. São Paulo: 1971.

SOUZA, Percival de. Autópsia do medo: vida e morte do Delegado Sergio Paranhos Fleury. São Paulo: Globo, 2000

USTRA, Carlos Alberto Brilhante. Rompendo o silêncio. Edição Digital, 1987. 